\title{
STRATEGI APOLOGI DALAM WACANA PERCAKAPAN DI BALAI DIKLAT KEAGAMAAN SURABAYA
}

\author{
Jamal \\ Balai Diklat Keagamaan Surabaya \\ e-mail: jamalkoe@yahoo.co.id
}

\begin{abstract}
This study aims to explain apology types and strategies in conversational discourses in the Religious Training Office Surabaya. The data sources were people involved in the training activities, including tutors/lecturers and participants. The data were collected through participant observations, in-depth interview, and documents. The data were analyzed by means of the interactive, simultaneous, and continuous technique developed by Miles and Huberman. The data analysis activities included (1) data reduction, data display, and conclusion drawing/inference. The findings are as follows. First, the anticipatory apology appears as frequently as the remedy apology. Apologies are stimulated by elements of space, time, speech, inability, and strength. Second, apologies contain explicit excuses with reasons in order to reduce linguistic and non-linguistic malfunctions. Third, strategies employed in apologies are varied, depending on the purposes.
\end{abstract}

Keywords: apology, apology types and strategies, linguistic malfunctions

\section{PENDAHULUAN}

Pada awalnya wacana dan analisis wacana adalah cara khusus membicarakan dunia dan memahami dunia atau aspek dunia (Jorgensen dan Philips, 2002). Sekarang ini istilah wacana telah menjadi istilah umum dalam berbagai disiplin: teori kritis, sosiologi, linguistik, filsafat, psikologi sosial (Mills, 1997), bahkan meluas sampai pada wilayah idiologi dan politik (Fairclough, 1995). Akibatnya, kajian terhadap wacana berkembang secara beragam sesuai dengan segi kajian dan visi pengembangannya masing-masing. Para ahli sosiolinguistik, misalnya, memperhatikan wacana dari segi interaksi sosial. Deskripsi wacana ditekankan pada ciriciri konteks sosial. Ahli sosiolinguistik biasanya melaksanakan kajian analisis wacana berdasarkan penggunaan bahasa. Brown dan Yule (1983) menyatakan bahwa para ahli sosiolinguistik lebih menekankan penggunaan bahasa se- bagai alat komunikasi untuk memantapkan dan memperhatikan hubungan sosial.

Dalam memahami penggunaan bahasa sebagai alat komunikasi untuk memantapkan hubungan tersebut, Gumperz (1988) yakin hal itu melibatkan pemahaman presuposisi percakapan. Menurutnya, teori umum strategi wacana tidak bisa tidak dimulai dengan menspesifikasikan pengetahuan linguistik dan sosio-kultural yang diperlukan untuk menjelaskan secara bersamasama apakah keterlibatan percakapan dipelihara, kemudian dilanjutkan untuk menghadapi apakah kesimpulan percakapan sebenarnya yang dibuat oleh kultur, subkultur, dan situasional kekhususan interpretasi.

Analisis percakapan sebagai bidang penemuan yang berkembang terus selama dekade terakhir ini menurut Gumperz (1988) telah diperkaya dengan konstribusi dari sejumlah prespek- 
tif disipliner. Dalam beberapa tahun sekarang ini ahli bahasa dan ilmu sosial, menyadariketerbatasan pendekatan kaum positifis-empiristis dalam menelaah perilaku manusia, menyadari kebutuhan untuk pemahaman lebih mendalam pemanfaatan tanda-tanda verbal dalam proses kerjasama. Ahli bahasa formalisme gramatikal sukses menjelaskan proses kognitif yang berpengaruh dalam dekode kata dan kalimat, namun demikian sadar akan keterbatasan keberadaan teori gramatikal dan telah mulai mencari pendekatan-pendekatan baru untuk menelaah proses percakapan.

Dalam dua dekasi terakhir ini masalah apologi wacana percakapan sebagai bagian dari tindak menjaga, memelihara, dan memperbaiki hubungan sosial adalah masalah menarik perhatian orang banyak. Dapat disebutkan sebagai contoh: Cohen dan Olstain (1981) menyelidiki apologi antarsuku bangsa; Holmes (1998), Masita (2006) meneliti penggunaan apologi antarbangsa; Yanti (2001), Wouk (2006) mengamati apologi untuk menjalin hubungan formal antarorang dalam suatu lembaga; Lipson (1994) dan Nasional Report (2005) menjelaskan apologi antarnegara, Ludwig (2006) mengobservasi apologi antarteman. Chapman dan Thomas (2006) meneliti penerapan apologi pada segala macam hubungan, dari hubungan personal yang mendalam antara pasangan dekat, antarteman di tempat kerja. Bahkan menariknya lagi, Coomer (1999) meneliti apologi yang digunakan dalam komunikasi antar manusia dengan binatang piaraan.

Untuk menghindari apologi yang rusak atau tidak efektif, Chapman dan Thomas (2006) menyarankan agar orang yang minta maaf (apologizer) mempelajari "bahasa" orang yang dimintai maaf. Dalam menerima permintaan maaf, misalnya, sebagian orang lebih menekan- kan ekspresi penyesalan, sementara sebagian yang lain lebih menekankan pengakuan tanggung jawab atau membuat perbaikan atau penggantian. Oleh karena itu, apologizer perlu menyesuaikan bentuk bahasa apologi yang sesuai dengan orang yang dimintai maaf.

Hikmah yang dapat dipetik dari pengamatan mendalam Chapman dan Thomas adalah ketika kita mencari usaha untuk memperbaiki hubungan sosial bukan harus dimulai dengan gagasan besar, melainkan dengan gagasan yang simpel dan mendasar yang selama ini mungkin taken for granted, yaitu meminta maaf (Chapman dan Thomas, 2006). Oleh karena itu, tulisan ini berusaha menelaah dan menjelaskan strategi apologi dalam wacana percakapan di Balai Diklat Keagamaan (BDK) Surabaya. Dalam hal ini BDK dianggap sebagai masyarakat tutur (karena mereka menetap selama mengikuti pendidikan dan pelatihan) yang multikultural (karena meraka berasal dari daerah yang berbeda dan latar belakang etnis, kelas sosial, kebudayaan, dan sosiokultural yang berbeda pula).

\section{METODE}

Penelitianinibertujuanmendapatkan eksplanasi tentang strategi apologi di BDK Surabaya. Untuk mencapai tujuan tersebut, data dikumpulkan dari seting alamiah yaitu komunikasi lisan yang terjadi di lingkungan BDK, peneliti bertindak sebagai instrumen utama, dan lebih mengutamakan proses di samping hasil. Data yang terkumpul berwujud tuturan dan akan dianalisis secara induktif. Berdasarkan ciri-ciri tersebut, penelitian ini menggunakan pendekatan kualitatif (Bogdan dan Biklen, 1998).

Dalam penelitian ini apologi dipandang sebagai tindak tutur dan produk tindak tutur. Sebagai tindak tutur dan produk tindak tutur, apologi akan dideskripsikan berdasarkan isi, fungsi, 
dan situasi tutur. Untuk mendeskripsikan isi, fungsi, dan situasi tutur, penelitian ini menggunakan cara kerja, antara lain, prinsip kerjasama, teori tindak tutur, dan prinsip santun. Berdasarkan cara memandang dan cara kerjanya, penelian ini termasuk jenis penelitian sosiopragmatik (Leech, 1993).

Setiap situasi sosial dapat diidentifikasi berdasarkan tiga elemen utama: tempat, aktor, dan aktivitas (Spradley, 1980: 39). Sejalan dengan pernyataan tersebut, penelitian ini mengambil lokasi di BDK Surabaya dalam situasi widyaiswara melaksanakan tugas mendidik, mengajar, dan melatih (dikjartih) perserta diklat. BDK Surabaya beralamat di Jalan Ketintang Madya 92 Surabaya. BDK Surabaya merupakan lembaga pemerintah yang berada di bawah naungan Departemen Agama Republik Indonesia Propinsi Jawa timur. Di tempat ini diklat bagi pegawai departemen agama propinsi Jawa Timur diselenggarakan.

Kehadiran peneliti di lokasi penelitian mutlak diperlukan karena teknik pengumpulan data dilakukan dengan observasi partisipan. Namun demikian, dalam proses pengambilan data, kehadiran peneliti tidak disadari sumber data. Hal ini dilakukan untuk mendapatkan data yang alami.

Data utama pelitian ini berupa tuturan yang dihasilkan oleh sumber data. Sumber data penelitian ini adalah orang-orang yang terlibat dalam kegiatan kediklatan di kelas yang meliputi widyaiswara/dosen dan peserta diklat. Pengumpulan data penelitian ini dilakukan dengan teknik observasi partisipan, wawancara mendalam, dan dokumentasi. Observasi digunakan untuk menjaring data utama. Selain observasi, pengumpulan data juga dilakukan dengan wawancara mendalam dan dokumentasi. Wawancara mendalam dan domukentasi digunakan untuk mendapatkan data pendukung yang berupa informasi tentang identitas sumber data, konteks tuturan, dan latar belakang sosiokultural sumber data.

Analisis data dilakukan dengan mengikuti alur analisis data interaktif, simultan, dan berkelanjutan yang dikembangkan oleh Miles dan Huberman (1992:15-20). Kegiatan analisis data meliputi (1) reduksi data, (2) penyajian data, dan (3) penarikan kesimpulan/verifikasi. Alur kegiatan analisis data penelitian dapat digambarkan secara sederhana dengan bagan 1 .

Berdasarkan bagan tersebut diketahui bahwa dari sumber data diperoleh data penelitian berupa tuturan. Kegiatan selanjutnya adalah analisis data yang meliputi reduksi data, penyajian data, dan penyimpulan data. Pada tahap reduksi data, kegiatan yang dilakukan adalah mengidentifikasi dan melakukan pengkodean terhadap data. Kegiatan mereduksi data ini difokuskan pada wujud verbal apologi, wujud verbal respon apologi, jenis apologi, dan elemen pemicu apologi. Tahap berikutnya, hasil kegiatan reduksi data disajikan dalam klasifikasi-klasifikasi berdasarkan kriteria-kriteria tertentu sehingga memberikan gambaran yang mengarah pada pemerolehan jawaban masalah penelitian. Pada tahap penyimpulan kegiatan yang dilakukan adalah menginterpretasi data untuk menemukan pola-pola umum atau kecenderungan wujud verbal, jenis, elemen pemicu, strategi, dan parameter sosiokultural dalam tindak ADKLM di BDK Surabaya. Temuan ini bersifat sementara sampai dilakukan verifikasi secara heuristik. Setelah dilakukan verifikasi secara heuristik dan berulang hingga jenuh dan temuan sementara masih stabil, temuan sementara tersebut ditetapkan sebagai temuan penelitian.

Keabsahan data penelitian ini dicek dengan tiga cara, yaitu (1) memperpanjang pengamatan, (2) menggu- 
nakan ketekunan dan ketelitian dalam pengamatan, dan (3) menggunakan triangulasi. Perpanjangan pengamatan tergambar pada intensitas pergaulan dan lamanya waktu tinggal di lokasi penelitian. Ketekunan dan ketelitian diupayakan dengan cara mengulangulang pengamatan dan mengoreksi data serta catatan yang diperoleh. Pengulangan dan koreksi diharapkan memperkecil kesalahan pencatatan, klasifikasi, dan pengambilan kesimpulan tentang data. Triangulasi dilakukan dengan menggunakan trianggulasi sumber data, yaitu (1) mencocokkan dengan data yang diperoleh sebelum atau sesudahnya, (2) mencocokkan dengan data yang diperoleh dari sumber data dan situasi tutur yang berbeda, (3) dan berdiskusi dengan teman sejawat atau orang yang mempunyai otoritas. Triangulasi data yang demikian dipandang tepat sebagai usaha untuk memperoleh kesimpulan yang sahih (Miles dan Huberman, 1992).

\section{HASIL PENELITIAN DAN PEMBA- HASAN \\ Jenis-Jenis Apologi}

Aijmer (1996) mengklasifikasikan apologi dalam wacana tutur menjadi dua kelompok utama, yaitu apologi antisipatori dan apologi retrospektif. Apologi antisipatori biasanya muncul sebelum melakukan prilaku yang membuat ketidaknyamanan dan berfungi untuk mengantisipasi, misalnya "Maaf, Pak. Boleh minta nomor telepon Pak Aziz?" Apologi retrospektif yang muncul sesudah prilaku tidak nyaman dan berfungsi untuk meremedi sesudah perilaku yang membuat tidak nyaman itu, misalnya "Saya kemarin agak tidak enak badan, tidak bisa hadir, mohon maaf."

Berdasarkan jenis apologi menurut Aijmer tersebut, tindak apologi dalam wacana percakapan di BDK Surabaya termasuk jenis apologi antisipa- tori:

(1) Mbok bilih mangke Bapak sempat ngendiko kaliyan Pak Kakanwil, ngapunten meniko, pun aturaken sepindah masalah kata sambutan saking Kanwil Jawa Tengah kaliyan Jawa Barat sekaliyan. [03]

Apologi tersebut termasuk jenis apologi antisipatori karena penutur akan memerintah mitra tuturnya untuk menyampaikan sekalian masalah kata sambutan. Memerintah adalah tindak imposif, sementara mitra tuturnya adalah kepala yang status kepegawaiannya di atasnya. Untuk mereduksi tindakan yang akan dilakukan itu, penutur menyatakan maaf.

Sementara itu, apologi jenis remidi yang ditemukan dalam percakapan antara lain (2), (3), (4) berikut.

(2) Sorry, yo. Terlambat. [06]

(3) Maaf, ya pak tadi terlambat. [08]

(4) Saya mohon maaf tidak bisa lagi membantu Bu Ana, seperti dulu. [12]

Pada contoh di atas dua apologi disampaikan berkaitan dengan perbuatan yang sudah lewat, yaitu terlambat mengikuti pelajaran. Mengikuti pelajaran adalah kewajiban peserta. Oleh karena itu, terlambat merupakan suatu kesalahan dan bisa mengimplikasikan makna lain bagi pengajar, misalnya hal itu berarti meremehkan pengajar. Demikian juga halya dengan permohonan maaf karena tidak bisa membantu lagi akhir-akhir ini.

Berdasarkan Ketulusannya, Mills (1997) membedakan apologi menjadi dua, yaitu genuine apoligy dan phony apology. Genuine apology adalah apologi yang tulus, sedangkan phony apology adalah apologi yang palsu. Pada apologi yang tulus diikuti dengan ikhtiar yang sungguh-sungguh untuk mengubah 
makna, peran, dan mengantisipasi dampak di masa kini dan yang akan datang. Sementara itu, pada apologi yang palsu permintaan maaf hanyalah merupakan lips service, tidak diikuti ikhtiar sungguh-sungguh untuk mengubah makna, peran, tindakan historis, dan aneka dampaknya pada masa kini dan masa depan. Dari data yang berhasil dikumpulkan tidak dijumpai apologi yang Dalam wacan percakapan di BDK Surabaya tidak ditemukan phony apologi.

\section{Elemen-Elemen Pemicu Ruang}

Elemen keruangan sebagai pemicu munculnya tindak apologi tidak lepas dari latar belakang sosiokultural antarpartisipan tutur. Seorang penutur merasa perlu menyatakan apologi atas penyediaan tempat atau ruang apabila penutur merasa tempat atau ruang itu mengganggu kenyamanan mitra tuturnya dan apabila tempat dan ruang yang disediakan itu kurang dari yang seharusnya. Misalnya apologi berikut.

(5) Mohon maaf, gedung ini memang tidak didesain untuk ruang diklat. Gedung ini dulunya adalah kantor wilayah. Jadi mohon maaf, bila ada yang kurang, misalnya tempat menjemur pakaian... dsb.

Namun, tempat dan ruang yang sama bukan merupakan pemicu timbulnya apologi apabila penutur yakin dengan tempat atau ruangan itu tidak mengganggu kenyamanan mitra tutur. Umumnya suatu tempat itu berpotensi menjadi pemicu atau tidak bergantung pada asal, kelas sosial, dan budaya mitra tutur. Mitra tutur yang berasal dari desa, kelas sosial menengah ke bawah, dan budaya yang relatif tradisional tidak mempersoalkan tempat atau ruang yang ada atau disediakan.

\section{Waktu}

Di Jepang bila diundang dalam suatu acara, orang pada umumnya akan datang tepat waktu. Tetapi di Siria keterlambatan hingga satu atau dua jam itu hal yang biasa. Elemen waktu sebagai pemicu munculnya tindak apologi tidak lepas dari latar belakang kebiasaan antarpartisipan tutur. Seorang penutur merasa perlu menyatakan apologi atas keterlambatan apabila penutur merasa terlambatnya itu mengganggu kenyamanan mitra tuturnya. Misalnya apologi berikut.

(6) Sorry, yo. Terlambat. [06]

(7) Maaf, ya Pak tadi terlambat. [08]

Selain faktor keterlambatan, faktor kekurangan atau kelebihan waktu juga potensial untuk menjadi pemicu timbulnya apologi apabila penutur yakin bahwa kekuranga atau kelebihan waktu yang disediakan mengganggu kenyamanan atau mengakibatkan sesuatu yang berarti. Seperti halnya tempat, umumnya sesuatu waktu itu berpotensi menjadi pemicu atau tidak bergantung pada asal, kelas sosial, dan budaya mitra tutur.

\section{Percakapan}

Perilaku selama percakapan berlangsung potensial menjadi pemicu munculnya tindak apologi apabila perilaku itu menggganggu kenyamanan partisipan tutur. Bertanya menyela selama percakapan berlangsung, minta klarifikasi suatu informasi, dan minta giliran berbicara atau giliran selebum waktu antrean tiba merupakan tindak menimbulkan ketidaknyamanan. Untuk mereduksi ketidaknyamanan itu biasanya dilakukan apologi. Berikut ini contoh apologi untuk menyela, minta klarifikasi, pemilikan.

(8) Maaf, tadi siapa Pak yang telefon saya? 
(9) Maaf, bisa diulang Pak (031) 58 ... 22 ... 32. Terima kasih.

(10) Ini milik Bapak, maaf. Saya tidak tahu. Silakan. Silakan.

Apologi yang muncul untuk tujuan bertanya sela, minta klarifikasi, minta waktu giliran berbicara, pada umumnya termasuk jenis apologi yang paling sering terjadi. Pada umumnya tindakan tersebut termasuk apologi ringan. Apologi semacam ini termasuk percakapan rutin.

\section{Ketidakmampuan}

Ada dua macam ketidakmampuan yang menyebabkan munculnya tindak apologi, yaitu ketidakmampuan sebagai individu dan ketidakmampuan sebagai pejabat. Ketidakmampuan individual ini umumnya disebabkan karena keterbatasan/kelemahan diri-sendiri yang tidak bisa melakukan sesuatu, sedangkan ketidakmampuan sebagai pejabat bisa terjadi sebagai diri-sendiri seseorang mungkin mampu, tetapi kedudukannya sebagai pejabat tidak membolehkan untuk melakukan sesuatu yang dimaksud. Dalam wacana percakapan di BDK tindak apologi dilakukan karena ketidakmampuan sebagai individu dapat ditemukan dalam percakapan berikut.

(11) Assalamu'alaikum (langsung menuju meja Pak Jamal). Mohon maaf, Pak. Saya sakit di kamar tadi. Saya sedang tidur dan teman saya tidak membangunkan. Mungkin dikira saya tidak memungkinkan untuk ikut pelajaran. [07]

Namun, pada umumnya apologi ditemukan disebabkan oleh ketidakmampuan sebagai pejabat. Contoh apologi ini antara lain.

(12) Saya mohon maaf tidak bisa lagi membantu Bu Ana, seperti dulu. Sejak saya kuliah ini, tugas banyak.
Waktu seperti kurang saja. [12]

(13) Saya betul-betul mohon maaf, Bu. Saya tidak bisa meninggalkan kuliah. Apa lagi itu ada Selasa dan Jum'at. ... mohon maaf. Kalau bisa diwakilkan yang lain saja. [13]

(14) A: Anu e, Pak. Pak Asma'ur mumpung di sini minta duluan. Ma'af ya Pak. (Pak Asma'ur WI senior rumahnya Lumajang.) [18]

B: Lho, ...

(15) A: Itulah permasalahannya, Pak. Sekarang bapak-bapak sudah bertemu, saya mohon maaf. Silakan dibicarakan bagaimana baiknya. [19] B: (sama-sama diam)

\section{Menunjukkan Kelebihan Orang Lain}

Menunjukkan atau membicarakan kelebihan orang lain di hadapan mintra tutur pada masyarakat yang berpendidikan atau bermartabat merupakan tindakan menyerang muka yang bisa me-nyebabkan ketidaknyamanan. Untuk itu tindak apologi segera dilakukan untuk mereduksi tingkat ketidaknyamanan tersebut. Umumnya tindak apologi ini berjenis apologi antisipasipatori. Misalnya contoh berikut.

(16) Ya, nyuwun sewu ada WI yang performancenya bagus, suaranya keras, body language-nya baik. Mohon maaf Pak Jamal, ya. Itu lho, Pak Wid. (WI Bahasa Inggris). Sesekali Pak Zuhdi masuk kelasnnya Pak Wid, biar tahu seperi apa mengajarnya ... Patataran berikutnya, ya ada Pak Dar (WI PKN), Pak Jamal ini ...(WI Bahasa Indonesia). [17]

\section{Pelanggaran Norma}

Pelanggaran norma sosiokultural merupakan merupakan tindak mencoreng muka sendiri ataupun orang lain. Termasuk dalam kategori pelanggaran norma ini misalnya pelanggaran adatistiadat, pelanggaran hukum positif, pelanggaran karena mengambil hak orang 
lain. Pelanggaran norma meliputi apologi personal maupun apologi umum. Berikut ini contoh apologi atas pelanggaran norma.

(17) Maaf, Mas. Sebetulnya tidak pantas saya menanyakan hak saya sebagai ahli waris. Tetapi, saya ini orang susah.

Pelanggaran norma yang berat, yang menyangkut masyarakat luas, mungkin tidak sesederhana itu. Pelanggar norma harus melakukan ritual, mengalami hukuman, atau membayar denda, di samping meminta maaf pada publik. Ada kalanya pelanggar norma diajukan ke pengadilan untuk mempertanggungjawabkan perbuatannya. Dalam wacana percakapan di BDK Surabaya yang telah teramati tidak ditemukan pelanggaran norma semacam itu.

\section{Kompleksitas Bahasa Apologi}

Apologi merupakan bentuk tanggung jawab apologizer atas perbuatan yang telah dilakukan (Austin, 1962; Searle, 1969). Kompleksitas apologi dalam penelitian ini merujuk pada satuan-satuan isi yang terkandung dalam bahasa apologi dan hal itu berkaitan dengan besar kecilnya tanggung jawab yang ditanggung oleh apologizer. Cohen and Olshtain (1981) menyatakan dalam bahasa apologi yang lengkap mengandung empat satuan isi. Kempat satuan-satuan isi itu adalah: (a) ekspresi apologi, (b) pengakuan atas tanggung jawab, (c) penawaran perbaikan atas kerusakan (jika ada), dan (d) jaminan untuk tidak terulang lagi di masa yang akan datang. Selanjutnya, Holmes (1998) berdasarkan penelitiannya terhadap penutur di Amerika menyimpulkan sebuah apologi yang lengkap berisi: (a) pernyataan eksplisit apologi, (b) penjelasan/alasan, (c) pengakuan tanggung jawab, (d) jaminan tidak mengulangi pelanggaran di masa yang akan datang.

Chapman and Thomas (2006) berdasarkan pengalamannya bertahuntahun menjadi konsultan beberapa perusahaan di New York menyarankan apologi di tempat kerja seharusnya mengandung lima satuan ini. Berikut ini kelima isi yang terkandung dalam apologi.

(a) Penyesalan, misalnya "Saya menyesal ..."

(b) Penerimaan, misalnya "Saya salah."

(c) Menawarkan ganti atas kerugian, misalnya "Apa yang dapat saya lakukan untuk memperbaiki ..."

(d) Kejujuran, misalnya "Saya usahakan untuk tidak melakukan kesalahan lagi."

(e) Permohonan maaf, misalnya "Maukah kau memaafkan aku?"

Sementaraitu, menurut Al-Qur'an (3:135) tanggung jawab bagi apologizer atas kesalahan yang telah diperbuat adalah: (a) meminta maaf, (b) mengakui/menyadari kesalahan, (c) berjanji tidak akan mengulangi kesalahan, (d) menyelesaikan hak adami (mengganti apabila ada kerusakan.

Dalam wacana percakapan di BDK Surabaya bahasa apologi pada umumnya dipicu oleh hal atau perbuatan pelanggaran yang tidak berat atau serius, sehingga bahasa apologinya tidak termasuk apologi yang kompleks. Pada umumnya apologi yang muncul mengandung (1) pernyataan maaf (eksplisit atau implisit), (2) pemberian penjelasan atau alasan, dan (3) janji untuk tidak terulang lagi tindakan pemicu apologi. Berikut ini contoh apologi eksplisit yang tidak diikuti penjelasan atau alasan.

(18) Pak Jamal, Pak Wid, maaf ya. [04]

(19) Mohon maaf Bapak/Ibu kita lanjutkan dengan seminar kedua. [11]

(20) A: Gini, mohon maaf, ya. [14] 
Apologi yang disertai penjelasan, alasan, bahkan ilustrasi yang lengkap tampak pada contoh berikut.

(21) A: Sorry, yo. Terlambat. Bukan saya yang salah. ...Kan bahan tes kemarin sudah saya tinggal di foto kopi. Saya bilang ini mau saya pakai besuk pagi. E, begitu pagi tadi saya ambil, belum selesai. Katanya tidak bisa mengkopi. Lho. Kok gitu? Kalau dia tidak bisa kan bsa bilang ke saya kalau tidak bisa. [06] (A6)

B: Ya, sudah.

(22) A: Anu e, Pak. Pak Asma'ur mumpung di sini minta duluan. Ma'af ya Pak. (Pak Asma'ur WI senior rumahnya Lumajang.) [18]

B: Lho, ...

(23) A: Itulah permasalahannya, Pak. Sekarang bapak-bapak sudah bertemu, saya mohon maaf. Silakan dibicarakan bagaimana baiknya. [19] B: (sama-sama diam)

Apologi yang dinyatakan secara eksplisit disertai alasan dan janji tidak mengulangi lagi tampak pada percakapan berikut.

(24) A: Mohon maaf, Pak. Saya sakit di kamar tadi. Saya sedang tidur dan teman saya tidak membangunkan. Mungkin dikira saya tidak memungkinkan untuk ikut pelajaran. [07]

B: Sakit apa?

(25) A: Maaf, ya pak tadi terlambat. Saya usahakan untuk dapat mengikuti pelajaran terus. [08]

B: nggak apa-apa

Dalam percakapan tersebut apologizernya adalah orang yang sama. Apologizer perlu menyatakan apologinya yang kompleks karena dalam situasi itu posisi apologizer adalah peserta, yang minus kekuyasaan relatif, tapi plus jarak sosialnya. Dalam percakapan pada umumnya bila apologizer sudah akrab dengan orang yang dimintai maaf, apologi yang sederhana sudah memadai, misalnya "Sorry, ya."

\section{Fungsi Apologi}

Secara umum fungsi apologi adalah untuk menjaga, memelihara, dan memperbaiki hubungan sosial. Cubajevaite dan Ruzaite (2008) menyatakan ada dua alasan utama orang melakukan apologi. Dua alasan itu adalah (a) apologi untuk kesalahan malfungsi linguistik dan (b) apologi untuk malfungsi nonlinguistik. Pada umumnya paling sering orang melakukan apologi karena malfungsi linguistik. Malfungsi linguistik meliputi mengulangi, interupsi, tidak setuju, meminta diulangi, terlalu detail, koreksi diri. Contoh masing-masingnya sebagai berikut.

(26) Masalah utamanya, dan istri Anda telah mengetahui hal ini dengan baik, maaf saya ulangi adalah ....

(27) Pak Muslimin, maaf, apakah Bapak sudah mengetahui kalau ...

28) Maaf saya kurang setuju mengenai hal itu, karena ...

(29) Maaf, bisa diulangi ...

(30) Maaf, sekali lagi maaf saya agak ngotot mengenai hal ini, karena saya pikir ...

(31) Saya mengajar sampai pukul 11.30 wib, sorry, 1230 wib.

Dalam wacana percakapan di BDK Surabaya, penggunaan apologi untuk memperbaiki malfungsi linguistik tampak pada contoh berikut.

(32) A: .... yaitu pertanyaan Nanda Iswati ....

B: Asmawati ...

A: Oh, maaf Nanda Asmawati. Kurang 'ma'-nya .... yaitu tentang lakilaki paling gampang untuk menjadi pemicu perceraian.[10]

(33) Maaf, bisa diulang Pak? (0341) 55 ...1 ... 752. Terima kasih. [20] 
Apologi yang berfungsi untuk malfungsi non-linguistik kemunculannya tidak sesering apologi malfungsi linguistik. Berikut ini contoh apologi ini.

(34) Sorry, yo. Terlambat. Bukan saya yang salah. ...Kan bahan tes kemarin sudah saya tinggal di foto kopi. Saya bilang ini mau saya pakai besuk pagi. E, begitu pagi tadi saya ambil, belum selesai. Katanya tidak bisa mengkopi. Lho. Kok gitu? Kalau dia tidak bisa kan bsa bilang ke saya kalau tidak bisa. [06]

(35) Maaf, ya pak tadi terlambat. Saya usahakan untuk dapat mengikuti pelajaran terus. [08]

(36) Anu e, Pak. Pak Asma'ur mumpung di sini minta duluan. Ma'af ya Pak. (Pak Asma'ur WI senior rumahnya Lumajang.)[18]

B: Lho, ...

\section{Strategi Apologi}

Sejumlah peneliti telah membuat sistem klasifikasi strategi apologi (Blum-Kulka,1989; Fraser, 1981; Cohen dan Olstain, 1981; Holmes, 1990). Pada umumnya klasifikasi yang dikembangkan dari ketertarikan pada pengajaran bahasa Inggris sebagai bahasa kedua. Berdasarkan klasifikasi mereka, strategi apologi yang muncul dapat diklasifikasikan secara garis besar ke dalam dua kategori, yaitu (1) apologi eksplisit dan (2) apologi implisit. Dua kategori strategi apologi itu dijelaskan dalam tabel 1.

\section{Peran Parameter Sosiokultural}

Aijimer (1996) menyatakan bahwa strategi yang paling langsung adalah minta maaf atau mohon maaf atau memintakan maaf seseorang. Strategi langsung melibatkan cost yang tinggi untuk muka penutur. Brown dan Levinson (1978) mengatakan bahwa beratnya maksud apologi sebagai ancaman muka harus dikalkulasi dengan mempertimbangkan tingkat keakraban dan hubungan kekuasaan partisipan yang terlibat, serta keseriusan ancaman. Semua faktor itu tampaknya mempengaruhi pilihan strategi apologi di BDK Surabaya. Hal itu tampak pada dominannya strategi apologi yang dinyatakan secara ekplisit. Bagan berikut menunjukkan makin langsung suatu tindak apologi, semakin tinggi cost yang harus dibayar.

Model Brown dan Levinson (1978) memprediksi bahwa lebarnya jarak sosial antara partisipan akan menghasilkan beratnya ketidaknyamanan. Tampaknya, semakin besar perbedaan kekuasaan antara penutur dan petutur, semakin serius ketidaknyamanan yang dihasilkan. Misalnya percakapan antarteman dekat, antara teman sejawat, dan antara dua orang asing, maka berdasarkan jarak sosial, maka dari antarteman sampai antara orang asing tingkat keseriusan makin meningkat.

Menentukan kekuasaan relatif antara peserta tutur sebenarnya pekerjaan yang tidak mudah. Salah satu faktornya adalah status relatif partisipan, namun faktor yang lain juga penting. Antara anak, misalnya, faktor usia adalah faktor penting. Pada konteks lain, pengalaman relatif, pengetahuan, atau kepiawaian merupakan masalah yang krusial. Dalam interaksi transaksional, peran partisipan, seperti pelanggan-pelayan, gurusiswa, mungkin lebih penting daripada status sosial relatif. Demikian juga jarak sosial atau tingkat keakraban antara penutur dan petutur. Hubungan antara kekuasaan dan keakraban dengan pilihan strategi yang dipilih disajikan pada bagan 1 dan 2 (Holmes, 1900).

\section{Apologi dalam Kajian Tindak Tutur}

Berbahasa menurut Austin (1962)

tidak hanya digunakan untuk menyampaikan makna proposional, sosial, sti- 
Tabel 1 Strategi Apologi (diadaptasi dari Aijmer, 1996)

\begin{tabular}{|c|c|c|c|}
\hline No & Strategi & Varian & Contoh \\
\hline \multirow[t]{2}{*}{1.} & $\begin{array}{l}\text { Eksplisit } \\
\text { Emosional }\end{array}$ & $\begin{array}{l}\text { Eksplisit } \\
\text { apologi }\end{array}$ & $\begin{array}{l}\text { Assalamu'alaikum (langsung menuju meja } \\
\text { Pak Jamal). Mohon maaf, Pak. Saya sakit di } \\
\text { kamar tadi. Saya sedang tidur dan teman saya } \\
\text { tidak membangunkan..[07] }\end{array}$ \\
\hline & & $\begin{array}{l}\text { Eksplisit } \\
\text { penyesalan }\end{array}$ & $\begin{array}{l}\text { Pak Jamal, Pak Wid, maaf ya. Tadinya mau } \\
\text { mengantarkan Pak Pak Jamal dan Pak Wid } \\
\text { biar cepat, e, malah menghambat hingga } \\
\text { malam begini. [04] }\end{array}$ \\
\hline \multirow[t]{3}{*}{2.} & $\begin{array}{l}\text { Eksplisit } \\
\text { Nonemosi } \\
\text { onal }\end{array}$ & $\begin{array}{l}\text { Memintakan } \\
\text { Maaf sese- } \\
\text { orang }\end{array}$ & $\begin{array}{l}\text { Pak Hamim minta maaf tidak bisa hadir } \\
\text { karena mengantarkan ayahnya kontrol. [01] }\end{array}$ \\
\hline & & $\begin{array}{l}\text { Mengharap- } \\
\text { kan maaf }\end{array}$ & $\begin{array}{l}\text { Maafkan saya jawab dulu pertanyaan dari } \\
\text { ibu-ibu, karena memang pertanyaannya } \\
\text { mengena. [09] }\end{array}$ \\
\hline & & $\begin{array}{l}\text { Menuntut } \\
\text { maaf pen- } \\
\text { dengar }\end{array}$ & $\begin{array}{l}\text { Saya mohon maaf tidak bisa lagi membantu } \\
\text { Bu Ana, seperti dulu. Sejak saya kuliah ini, } \\
\text { tugas banyak. Waktu seperti kurang saja. [12] }\end{array}$ \\
\hline 3. & $\begin{array}{l}\text { Implisit } \\
\text { Emosional }\end{array}$ & $\begin{array}{l}\text { Memberi } \\
\text { penjelasan } \\
\text { dan pertim- } \\
\text { bangan }\end{array}$ & $\begin{array}{l}\text { Ya, bagaimana lagi, Pak Jamal. Kalau tes } \\
\text { TOEFL kan tidak boleh diputus di tengah } \\
\text { jalan Pak Jamal. ) [05] }\end{array}$ \\
\hline \multirow[t]{4}{*}{4.} & $\begin{array}{l}\text { Implisit } \\
\text { Nonemosi } \\
\text { onal }\end{array}$ & $\begin{array}{l}\text { Meminimal- } \\
\text { kan diri sen- } \\
\text { diri }\end{array}$ & $\begin{array}{l}\text { Bukan saya yang salah. ...Kan bahan tes } \\
\text { kemarin sudah saya tinggal di foto kopi. Saya } \\
\text { bilang ini mau saya pakai besuk pagi. E, } \\
\text { begitu pagi tadi saya ambil, belum selesai. } \\
\text { Katanya tidak bisa mengkopi. Lho. Kok gitu? } \\
\text { Kalau dia tidak bisa kan bisa bilang ke saya } \\
\text { kalau tidak bisa. [06] }\end{array}$ \\
\hline & & $\begin{array}{l}\text { Mengakui } \\
\text { tanggung } \\
\text { jawab }\end{array}$ & $\begin{array}{l}\text { E, begini, Pak. Kami janjian sore ini pukul } \\
15.00 \text { wib, Pak. Tetapi, tadi beliaunya sms } \\
\text { saya katanya beliau sakit. [02] }\end{array}$ \\
\hline & & $\begin{array}{l}\text { Berjanji tidak } \\
\text { terjadi lagi } \\
\text { hal serupa }\end{array}$ & $\begin{array}{l}\text { Saya usahakan untuk dapat mengikuti } \\
\text { pelajaran terus.[08] }\end{array}$ \\
\hline & & $\begin{array}{l}\text { Menawarkan } \\
\text { penggantian/ } \\
\text { pembayaran }\end{array}$ & $\begin{array}{l}\text { Saya tidak bisa meninggalkan kuliah. Apa } \\
\text { lagi itu ada Selasa dan Jum'at. .... Kalau bisa } \\
\text { diwakilkan yang lain saja. [13] }\end{array}$ \\
\hline
\end{tabular}



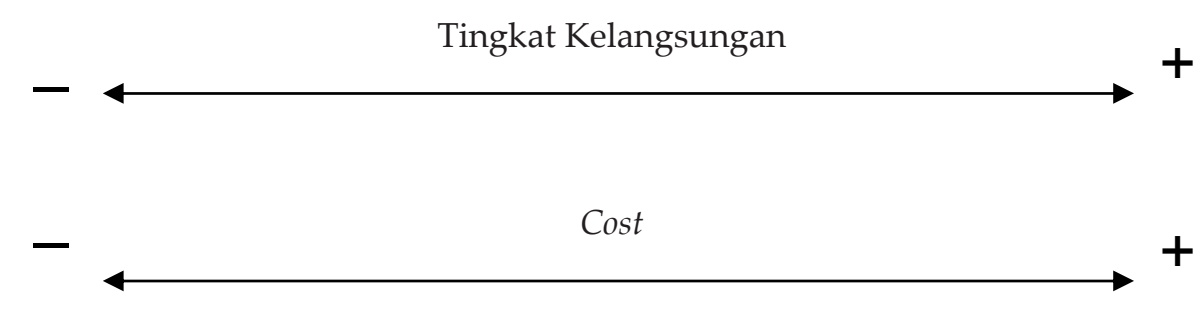

Bagan 1 Hubungan Kelangsungan dengan Cost Apologi
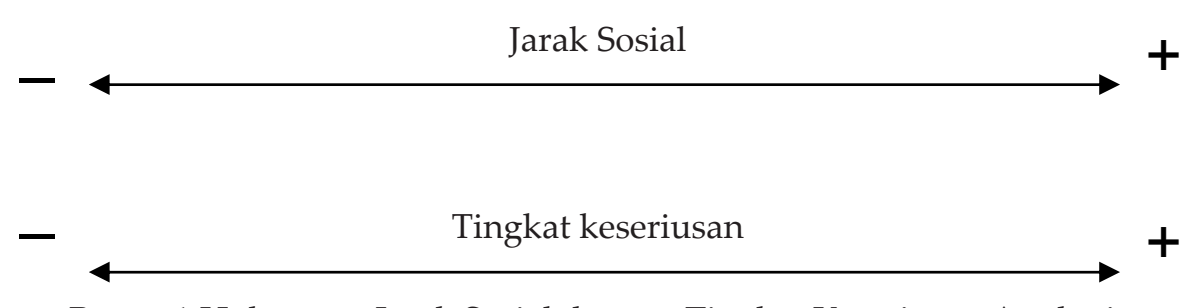

Bagan 1 Hubungan Jarak Sosial dengan Tingkat Keseriusan Apologi

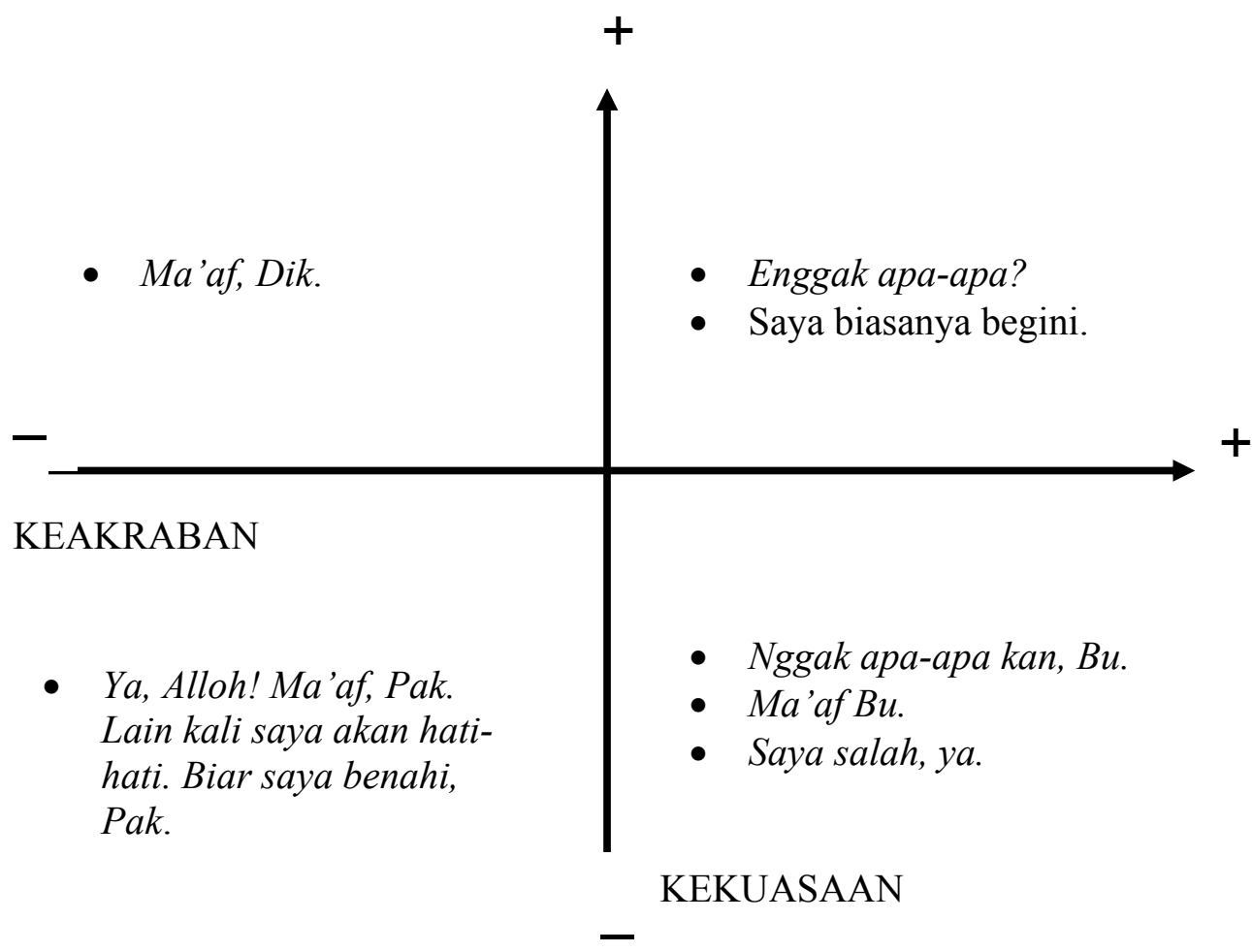

Bagan 2 Hubungan Kekuasaan dan Keakraban dengan Strategi Apologi 
listik, dan afektif seperti pandangan konvensional yang berlaku selama ini, tetapi juga digunakan untuk melakukan tindakan. Konsep yang paling mendasar dari pandangan Austin adalah tuturan (speech) sebagai tindakan yang berupa tidak tutur (speech act) mencakup tiga macam tindakan, yaitu tindak lokusi (locutionary act), tindak ilokusi (illocutionary act), dan tindak perlokusi (perlocutionary act). Ketiga tindakan itu dapat disebut secara singkat sebagai lokusi, ilokusi, dan perlokusi. Lokusi adalah tindakan berbicara, yaitu tindak mengucapkan suatu tuturan bermakna, baik makna harfiah atau kata per kata maupun makna kalimat. Ilokusi adalah tindak melakukan sesuatu. Ilokusi berkaitan dengan maksud, fungsi, dan daya yang terkandung dalam lokusi. Perlokusi adalah akibat yang ditimbulkan oleh adanya ilokusi di dalam lokusi (Austin, 1962; Brown dan Lavinson, 1978; Leech, 1993).

Ilokusi dapat digolongkan berdasarkan isi dan fungsinya. Dari segi isi, Searle (1969) mengklasifikasikan ilokusi ke dalam lima kategori, yaitu asertif, direktif, komisif, ekspresif, dan deklaratif. Ilokusi asertif adalah tindak tutur yang mengikat $\mathrm{N}$ pada kebenaran proposisi yang diungkapkan. Ilokusi asertif ini sering juga ilokusi representatif. Contoh ilokusi jenis ini, misalnya, menyatakan, mengusulkan, mengeluh, mengemukakan pendapat, melaporkan, dan membual. Umumnya ilokusi jenis ini termasuk kategori kerja sama kecuali membual yang biasanya dianggap tidak santun. Ilokusi asertif bersifat proposional, yaitu maknanya berada dalam proposisi makna tekstual.

Ilokusi direktif adalah tindak tutur yang bertujuan menghasilkan suatu efek berupa tindakan yang dilakukan T. Menurut Leech (1993), meskipun ilokusi direktif menghasilkan efek "menggiring $\mathrm{T}$ untuk melakukan suatu tindakan", tidak semua direktif bermakna kompetitif sehingga tergolong tindak tutur yang kurang santun. Ada sebagian direktif yang secara intrinsik cukup santun, misalnya mengundang, tetapi ada pula yang sebagian yang secara intrinsik kurang santun, misalnya memerintah.

Ilokusi komisif adalah tindak tutur yang sedikit-banyak mengikat $\mathrm{N}$ dengan suatu tindakan masa depan. Contoh ilokusi ini, misalnya, menjanjijkan, menawarkan, dan berkaul (bernadar). Ilokusi ini cenderung bersifat menyenangkan daripada bersifat kompetitif karena tidak mengacu pada kepentingan $\mathrm{N}$, tetapi kepentngan $\mathrm{T}$.

Ilokusi ekspresif adalah tindak tutur yang berisi ungkapan sikap psikologis $\mathrm{N}$ terhadap situasi yang tersirat dalam lokusi, Contoh ilokusi ini, misalnya, mengucapkan terima kasih, mengucapkan selamat, memberi maaf, mengecam, memuji, menuduh, dan mengucapkan bela sungkawa. Sama halnya dengan komisif, ilokusi ekspresif juga bersifat menyenangkan. Berdasarkan sifatnya itu, secara intrinsik ilokusi ini umumnya termasuk santun, kecuali mengecam dan menuduh.

Ilokusi deklaratif adalah tindak tutur memberi akibat tertentu pada $\mathrm{T}$ berdasarkan kesesuaian antara isi proposisi dengan realitas. Termasuk ilokusi ini, misalnya, pernyataan memecat, memberi nama, membabtis, mengundurkan diri, menjatuhkan hukum, dan mengangkat pegawai. Ilokusi ini biasanya dihubungkan dengan lembaga dan wewenang atau otoritas yang dimiliki $\mathrm{N}$ oleh karena tidak menyangkut individu-individu, ilokusi ini sama sekali tidak berhubungan dengan kesantunan.

Leech (1993) membuat kategori ilokusi berdasarkan fungsinya menjadi empat kategori yaitu ilokusi yang berfungsi kompetitif (competitive), menyenangkan (convivial), bekerja sama (collaborative), menentang (conflictive). Tujuan 
ilokusi kompetitif bersaing dengan tujuan sosial, yaitu tujuan untuk memelihara hubungan baik antara $\mathrm{N}$ dengan $\mathrm{T}$ dan menjaga agar $\mathrm{T}$ tidak merasa malu, tertekan, terpaksa, dan terancam. Termasuk ilokusi kompetitif ini, misalnya, memerintah, meminta, menuntut, dan mengemis. Tujuan ilokusi menyenangkan (convivial) sejalan denagan tujuan sosial. Termasuk tujuan ini, antara lain, menawarkan, mengundang, menyapa, mengucapkan terima kasih, dan mengucapkan salam. Tujuan ilokusi yang berfungsi bekerja sama (collaborative) tidak menghiraukan tujuan sosial. Termasuk tujuan ini adalah menyatakan, melaporkan, mengumumkan, dan mengajarkan. Sementara itu tujuan ilokusi yang menentang (conflictive) bertentangan dengan tujuan sosial. Termasuk ilokusi ini antara lain, mengancam, menuduh, menyumpahi, dan memarahi. Fungsifungsi tersebut dihubungkan dengan tujuuan-tujuan sosial untuk memelihara perilaku yang santun dan terhormat. Dua dari empat jenis fungsi ilokusi tersebut berkaitan dengan apologi, yaitu ilokusi kompetitif (competitive), dan menyenangkan (convivial).

Istilah imposif (IMP) diberikan oleh Leech (1993) untuk menyebutkan sebagian dari ilokusi direktif (dalam klasifikasi menurut Searle, 1975) yang termasuk kategori kompetitif (dalam klasifiksai menurut Leech, 1993). Leech menyatakan IMP bertujuan menghasilkan suatu efek berupa tindakan yang dilakukan T. Pada umumnya IMP termasuk tindakan mengancam muka $\mathrm{T}$, membatasi $\mathrm{T}$ untuk tidak melakukan tindakan. Tindak memerintah, misalnya, termasuk tindak mengancam muka T. Oleh karena itu, ilokusi ini memerlukan strategi untuk mereduksi tingkat ancaman suatu tuturan terhadap muka negarif $\mathrm{T}$, salah satunya ialah dengan modus meminta maaf, misalnya (37)
(37) A: Pedas. Ambilkan tehnya, Pak. Maaf ya.

(38) B: Ok.

Di sisi lain, tindak IMP mungkin secara pragmatik dapat dikategorikan sebagai tindak yang santun karena kemungkinan konteks tutur mendukung tindak tersebut sebagai tindak santun. Tindak memerintah, misalnya, tetap tergolong tindak yang santun jika $\mathrm{N}$ yang memerintah memiliki wewenang untuk melakukan perintah terhadap T.

Tindakan IMP tidak selalu (hanya) mengancam muka T. Ada kalanya tindakan IMP dapat memberikan efek berupa ancaman terhadap muka N. Memuji sebagai modus memerintah, misalnya, di satu sisi mengancam muka $\mathrm{T}$ karena membatasi $\mathrm{T}$ untuk melakaukan tindakan. Namun di sisi lain, mengancam muka $\mathrm{N}$ karena menempatkan $\mathrm{N}$ pada posisi mengakui kelebihan $\mathrm{T}$ dan kekurangan pada diri N.

Dipandang dari segi maksud dan daya, pemahaman terhadap IMP bergantung pada tingkat ketransparanan. Ada ilokusi-ilokusi IMP yang mengandung makna literal sehingga pemahamannya cukup secara konvensional atau dimaknai secara literal. Ada pula IMP yang mengandung makna nonliteral sehingga pemahamannya dilandasi oleh premis-premis kontekstual. Premispremis kotekstual meliputi pemahaman terhadap persepsi $\mathrm{N}$ dan $\mathrm{T}$, pengetahuan pendahuluan, pemahaman terhadap pola-pola interaksi, pemahaman tenatang 'dunia' (knowledge of the world), dan referensi yang menyangkut kondisi mental, pengamalan, dan kepribadian. Dengan kata lain, di dalam kerangka memahami IMP, baik N maupun T dipersyaratkan memiliki kompetensi linguistik dan kompetensi sosial (Wardhough, 1986: 362). Komptensi linguistik dan kompetensi sosial tersebut hendaknya 
harmonis dan sebangun dengan lokusi (apa yang dikatakan), ilokusi (apa yang dimaksudkan), dan perlokusi (apa yang dilakukan) sehingga komunikasi berjalan dengan lancar dan mencapai tujuan.

\section{Apologi dalam Tuturan Langsung dan Tidak Langsung}

Pengertian tindak tutur langsung (TL) dan tindak tutur tak langsung (TTL) berkaitan dengan pandangan bahwa dalam percakapan partisipan tidak selalu mengatakan apa yang dimaksudkan. Searle (1975) menyatakan fenomena ini sebagai penggunaan ilokusi tidak langsung (indirect illocution) atau tidak tutur tak langsung (indirect speech act), yaitu tindak yang dilakukan secara tidak langsung melalui tindak ilokusi lain. Pengertian TL dan TTL berhubungan dengan dua dimensi, yaitu pilihan pada bentuk dan pilihan pada isi.

Dimensi pertama merealisasikan submaksim maksim cara (MC), yang menyangkut bagaimana suatu tuturan diformulasikan, bagaimana bentuk satuan pragmatik (SP) yang dipakai untuk mewujudkan ilokusi itu. Sementara itu, pilihan pada isi ilokusi menyangkut maksud yang terkandung pada ilokusi itu. Jika isi ilokusi mengandung maksud yang sama dengan makna performansinya, maka ilokusi itu disebut TL. Sebaliknya, jika maksud suatu ilokusi berbeda dengan makna performansinya maka ilokusi itu disebut TTL. Sebagai contoh, dari segi bentuk, (66) berlawanan dengan (67), tetapi isi ilokusi keduanya sama, yakni melakukan tindakan apologi. Dari segi ini ilokusi, (66) lebih langsung.

(39) Maafkan saya, ya.

(40) Ya beginilah kalau orang tua yang mengerjakan.(Mengakui kelemahan diri sendiri dalam melakukan sesuatu yang kurang sempurna sebagai modus apologi)
Dari sudut pandang bentuk ilokusi, untuk memilih menggunakan TL ataukah TTL, N dihadapkan pada pilihan mematuhi submaksim MC (i) "Hindari pernyataan yang samar" dan (ii) "Hindari ketaksaan" dengan mematuhi submaksim (iii) "Usahakan agar pernyataannya ringkas."

Dimensi kedua berhubungan dengan realisasi submaksim maksim kuantitas (MN), yaitu berupa pilihan antara diam dan bicara. Submaksimsubmaksim MN berbunyi (i) "sumbangan informasi anda harus seinformatif yang dibutuhakan"; dan submaksim (ii) "Sumbangan informasi Anda jangan melebihi yang dibutuhkan". Submaksimsubmaksim ini mengarahkan $\mathrm{N}$ untuk mengatakan sesuatu sebatas pada apa yang dibutuhkan dalam percakapan. Hal itu berarti bahwa partisipan hendaknya memilih hanya ilokusi-ilokusi yang gayut dengan topik penuturan dan tidak memilih ilokusi-ilokusi yang tidak informatif atau menyimpang dari topik penuturan. Dengan melakukan pelanggaran terhadap submaksim MC dan MN, maka akan menghasilkan informasi yang tidak jelas. Dalam keadaan ketidakjelasan ini menjadi tugas T untuk menentukan interpretasi ilokusi sebuah Tt yang telah diucapkan $\mathrm{N}$ dengan strategi heuristik.

\section{Apologi dalam Model Interaksi Sosial}

Sebuah apologi pada dasarnya dan esensinya adalah tindak sosial. Tindak ini dimaksudkan untuk memelihara hubungan baik antarpartisipan. Melakukan tindak apologi adalah bertindak secara santun, baik dalam suasana akrab maupun dalam suasana lebih teknis dalam pemberian perhatian atas kebutuhan muka T (Brown dan Levinson 1978). Apologi ini berkaitan dengan pandangan kaum Gracian (1975) tentang percakapan santun sebagai penyimpang- 
an (deviasi) dari percakapan yang rasional dan efektif.

Sebuah model yang memperhitungkan penekanan dalam interaksi menunjukkan bahwa partisipan memakai makna referensial versus makna sosial dalam tipe interaksi yang berbeda. Hal ini menunjukkan bahwa segi empat grafik atau plots dua-dimensional membe- rikan sebuah model yang menunjukkan kesalingtergantungan dari dua dimensi penting dalam interaksi, yaitu makna sosial dan makna afektif pada satu sisi dan makna referensial atau informasi proposional di sisi lain. Model ini memfasilitasi dengan baik analisis interaksi, khususnya apologi. Bagan 3 menjelaskan posisi apologi dalam interaksi.

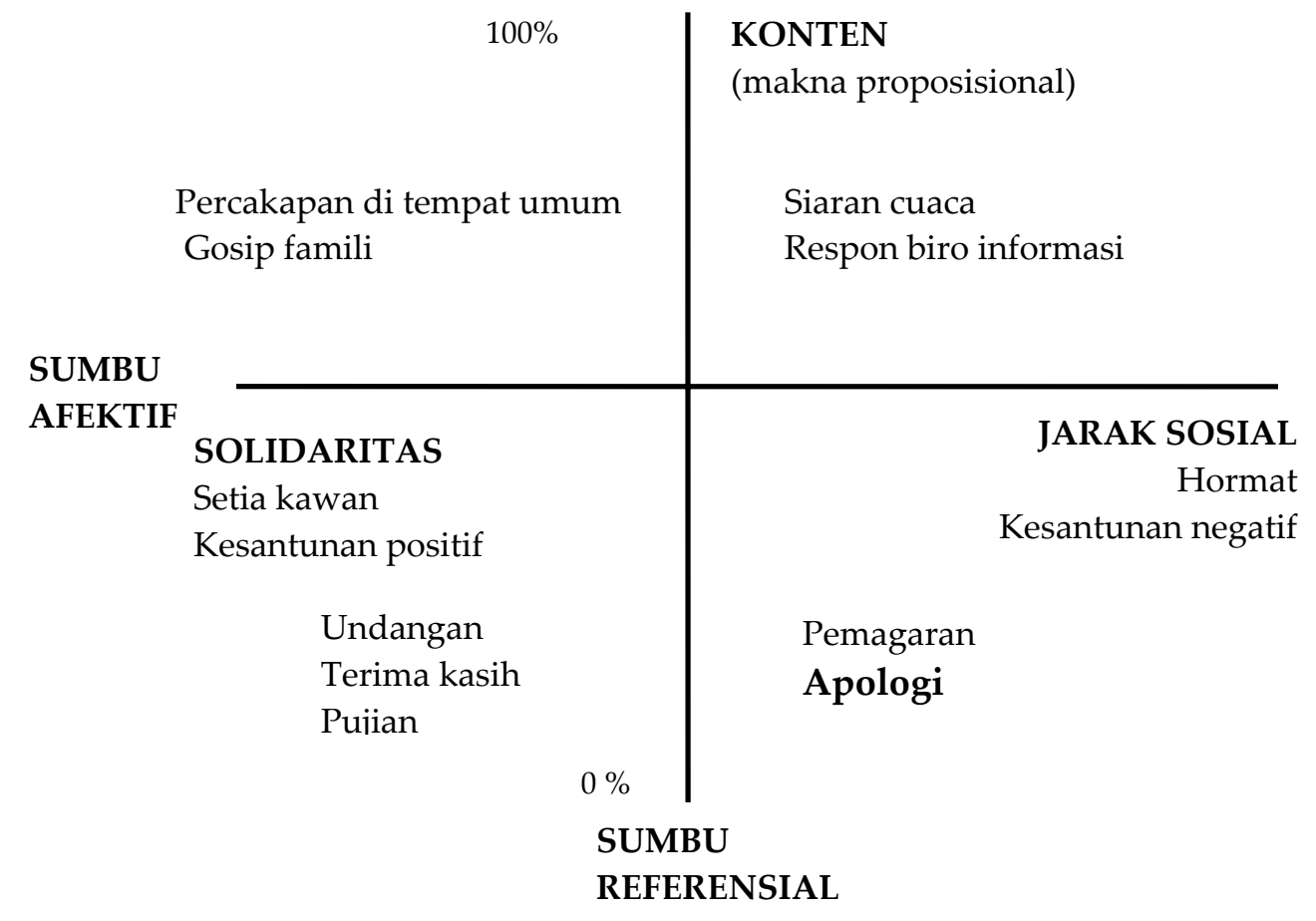

Bagan 3: Model Plots Dua-dimensional Kesalingtergantungan Apologi dalam Interaksi (diadaptasi dari Holmes, 1990)

Area pada empat kuadron mewakili ruang interpersonal. Pernyataan, ekspresi, atau interaksi mungkin ditempatkan pada ruang itu sesuai dengan keluasan ke mana hal itu diekspresikan baik konteks referensial, dalam skala 0 - 100 persen, maupun makna afektif pada skala yang bergerak dari solidaritas tinggi pada satu ujung dan jarak atau pertahanan sosial maksimal pada ujung yang lain. Model demikian menuntut analisis interaksi sebagai ekspresi simultan baik konteks proposional maupun makna afektif. Perhatian yang diberikan pada masing-masing akan berbeda dalam tingkatan pada situasi tertentu. Oleh karena itu, sebuah respon, misalnya, Jam 3, pada pertanyaan-menginginkan informasi misalnya, Jam berapa sekarang? mungkin ditempatkan dekat pada puncak sumbu vertikal untuk diperhitungkan tingginya isi informasi 
pada konteks tertentu, sementara sebuah sapaan, sebuah pujian, atau sebuah apologi mungkin akan ditempatkan di bawah pada sumbu referensial namun pada dimensi solidaritas atau kesantunan positif di ujung sumbu dimensi afektif, mencerminkan fakta bahwa tindak ujar demikian mengusung sedikit isi referensial namun mengekspresikan sebuah pesan yang tinggi pada afektif atau makna sosial.

Model tersebut mempunyai implikasi yang sangat spesifik. Meskipun sumbu referensial menghadirkan skala membentang dari referensial minimum atau isi proposisional di bawah ke isi referensial maksimum di atas, sumbu afektif tidak menunjukkan sebuah skala minimum ke maksimal afek (pengaruh). Bahkan poin yang berbeda sepanjang sumbu mewakili efek atau derajat yang berbeda yang diperhitungkan oleh penutur terhadap kebutuhan muka positif versus muka negatif petutur. Sumbu afektif itu mengombinasikan konsep Brown dan Levenson (1987) tentang Kekuasaan (Power) dan Jarak (Distance). Skala ini memungkinkan hal itu untuk memperhitungkan pernyataan yang mengekspresikan solidaritas yang sangat dominan atau perbedaan jarak sosial sementara, juga menggambarkan fakta bahwa pernyataan tertentu boleh jadi mempunyai elemen-elemennya masing-masing.

\section{SIMPULAN}

Berdasakan hasil telaah apologi dalam wacana percakapan di BDK Surabaya dapat disimpulkan bahwa jenis apologi yang muncul adalah apologi antisipatori sama seringnya dengan apologi remedi, faktor pemicu timbulnya apologi adalah berkaitan dengan elemen keruangan, waktu, percakapan, ketakmampuan, menunjukkan kelebihan orang lain. Pada umumnya tingkat keseriusan pemicu tergolong ringanringan saja.

Dari segi kompleksitasnya, apologi di BDk termasuk apologi yang tidak terlalu komplek. Pada umumnya apologi mengandung pernyataan maaf yang eksplisit disertai alasan dengan fungsi untuk mereduksi malfungsi linguiatik dan malfungsi non-linguistik. Sejalan dengan tingkat kompleksitas dan keseriusan faktor pemicu itu, strategi yang ditempuh untuk menyatakan apologi pada umumnya adalah (1) strategi langsung atau eksplisit, (2) diikuti penyesalan, (3) memintakan maaf orang lain, (4) mengharapkan maaf, (5) menuntut maaf, (6) memberi penjelasan dan pertimbangan, (7) merendahkan diri, (8) mengakui tenhggung jawab, (9) berjanji tidak mengulangi lagi, (10 ) menawarkan perbaikan. Disamping itu partisipan tutur juga menggunakan beberapa strategi sekaligus.

\section{UCAPAN TERIMA KASIH}

Artikel ini diangkat dari penelitian mandiri swadana yang dilaksanakan pada tahun 2009. Ucapan terima kasih disampaikan kepada mitra sejawat yang telah membantu kegiatan verifikasi dan triangulasi data dan hasil penelitian. Ucapan terima kasih juga disampaikan kepada Prof. Dr. Suparno selaku pengampu mata kuliah Kajian Wacana di Program Pascasarjana Universitas Negeri Malang yang telah memberi arahan, bimbingan aspek-aspek teroritik dalam kaitannya dengan kajian wacana.

\section{DAFTAR PUSTAKA}

Blum-Kulka, S, S, House, J, dan Kasper, G. 1989. Cross Cultural Pragmatics: Requests and Apologies. Norwood, NJ: Abex.

Brown, G. dan Yule, G. 1996. Discourse Analysis. Cambridg: Cambridg University Press. 
Brown, P. dan Levinson, S.D. 1978. Politeness: Some Universals in Language Usage. Cambridge University Press.

Chapman, G. dan Thoman, J. 2006. The Five Language of Apology: How to Experience Healing in All Your Relationships. http://www.bcwinstitute. com/press/ApologyStudyGuide Workplace.pdf 1 September 2006. Diakses 25 Maret 2008

Cohen, A.D. dan Olstain, E. 1981. Developing a Measure of Sociocultural Competence: the Case of Apology. Dalam Language Learning. A Journal of Applied Linguistics. Vol. 31 nomor 1 Juni 1981.

Fairclough, N. 1995. Critical Discourse Analysis the critical study of Language. London and New York. Longman.

Fraser, B. 1978. "Acquiring Social Competence in A Second Language". Relc. Journal. 9 (2): 1-21.

Gumperz, J.J. 1988. Discourse Strategies: Studies in Interactional Sociolinguistics 1. Cambridge Cambridge University Press.

Holmes, J. 1990. Apologies in New Zealand English. Dalam Chesire, J. dan Trudgill, P. (eds.). 1998. The Sociolinguistics Readers Volume 2: Gender and Discourse (Hlm. 201239).

Jorgensen, M.W dan Philips, L. 2002. Discourse Analysis as Theory and Method. London: Sage Publications Ltd.
Kuntarto, E. 1999. Strategi Kesantunan Dwibahasawan Indonesia-Jawa: Kajian pada Wacana Lisan Bahasa Indonesa. Disertasi tidak diterbitkan. Malang: Program Pascasarjana IKIP Malang.

Leech, G. 1993. Prinsip-Prinsip Pragmatik. Terjemahan M.D.D Oka. Jakarta: Penerbit Universitas Indonesia.

Lipson, M. 1994. Apologizing in Italian and English. Dalam IRAL, International Review of Applied Linguistics in Language Teaching. Vol. XXXII/1 February 1994.

Ludwig, T dan Manning, MJ. 2006. Sorry! www.httm:Amazon.com. 15 Juli 2006. diakses 7 Januari 2008.

Magnis-Suseno, F. 1999. Etika Jawa: Sebuah Analisa Falsafi tentang Kebijaksanan Hidup Jawa. Jakarta: Gramedia Pustaka Umum.

Masita, E. 2006. Apology: Cross-Cultural Speech Act Realization Patterns. Dalam Lingua. Vol.7. No.2. Juni 2006.

Mills, S. 1997. Discourse. London and New York. Routledge.

Wouk, F. 2006. The Language of Apologizing in Lombok, Indonesia. Jurnal Pragmatik. [digital]. www.httm: Amazon.com. 1 Oktober 2006. Diakses 7 Januari 2008.

Yanti, Y. 2001. Tindak Tutur Maaf di dalam Bahasa Indonesia di Kalangan Penutur Minangkabau. Linguistik Indonesia. Jurnal Ilmiah Masyarakat Linguisik Indonesia. No.1 tahun 19 Feruari 2001. 